University of New Hampshire

University of New Hampshire Scholars' Repository

10-30-1992

\title{
Beryllium 7 and Lead 210 in the western hemisphere Arctic atmosphere: Observations from three recent aircraft-based sampling programs
}

Jack E. Dibb

University of New Hampshire, jack.dibb@unh.edu

R. Talbot

University of New Hampshire

G L. Gregory

NASA

Follow this and additional works at: https://scholars.unh.edu/earthsci_facpub

Part of the Atmospheric Sciences Commons

\section{Recommended Citation}

Dibb, J. E., R. W. Talbot, and G. L. Gregory (1992), Beryllium 7 and Lead 210 in the western hemisphere Arctic atmosphere: Observations from three recent aircraft-based sampling programs, J. Geophys. Res., 97(D15), 16709-16715, doi:10.1029/91JD01807.

This Article is brought to you for free and open access by the Earth Sciences at University of New Hampshire Scholars' Repository. It has been accepted for inclusion in Earth Sciences Scholarship by an authorized administrator of University of New Hampshire Scholars' Repository. For more information, please contact Scholarly.Communication@unh.edu. 


\title{
Beryllium 7 and Lead 210 in the Western Hemisphere Arctic Atmosphere: Observations From Three Recent Aircraft-Based Sampling Programs
}

\author{
JACK E. DIBB \\ Glacier Research Group, Institute for the Study of Earth, Oceans and Space, \\ University of New Hampshire, Durham \\ Robert W. TALbot \\ Global Atmospheric Chemistry Group, Institute for the Study of Earth, Oceans and Space, \\ University of New Hampshire, Durham \\ GERALD L. GREGORY
}

Atmospheric Sciences Division, NASA Langley Research Center, Hampton, Virginia

\begin{abstract}
Concentrations of the natural radionuclides ${ }^{7} \mathrm{Be}$ and ${ }^{210} \mathrm{~Pb}$ were determined in aerosol samples collected in the western hemisphere Arctic during the recent NOAA Arctic Gas and Aerosol Sampling Program (AGASP 3) and NASA Global Tropospheric Experiment/Arctic Boundary Layer Expeditions (GTE/ABLE 3A and ABLE 3B) missions. Beryllium 7 showed a free tropospheric concentration maximum between 4 and $5 \mathrm{~km}$ in the summer of 1990 . Previous ${ }^{7} \mathrm{Be}$ data obtained in the late $1950 \mathrm{~s}$ and early 1960 s also indicated a similar vertical distribution of ${ }^{7} \mathrm{Be}$ near $70^{\circ} \mathrm{N}$. Injection of stratospheric air through tropopause folds associated with the Arctic jet near $70^{\circ} \mathrm{N}$ appears to explain the presence of a layer of air near $4-5 \mathrm{~km}$ in the high Arctic free troposphere with elevated ${ }^{7} \mathrm{Be}$ concentrations. The vertical distribution of ${ }^{210} \mathrm{~Pb}$ showed a distinct difference between the high-Arctic and sub-Arctic in the summer of 1988 . At latitudes greater than $65^{\circ} \mathrm{N},{ }^{210} \mathrm{~Pb}$ concentrations at $3-6 \mathrm{~km}$ were elevated compared to those below $1 \mathrm{~km}$. The reverse of this trend was observed near $60^{\circ} \mathrm{N}$. These same vertical distributions were also apparent in aerosol $\mathrm{SO}_{4}^{2-}$, determined in separate aerosol samples collected on the same flights (Talbot et al., this issue). The results for ${ }^{210} \mathrm{~Pb}$ suggest that some of the difference between the summer troposphere in the high- and sub-Arctic is also due to enhanced stratospheretroposphere exchange in the vicinity of the Arctic jet. These observations, and other findings from ABLE 3A presented in this issue, suggest that for some species the stratosphere may be a principal source influencing their distribution in the Arctic summer troposphere. For example, intrusions of stratospheric air constitute the dominant source term for tropospheric budgets of ${ }^{7} \mathrm{Be}$ and ozone, and may be important in the ${ }^{210} \mathrm{~Pb}, \mathrm{SO}_{4}^{2-}$, and $\mathrm{NO}_{y}$ budgets. Further investigation, including determination of detailed ${ }^{7} \mathrm{Be}$ and ${ }^{210} \mathrm{~Pb}$ distributions, is needed to quantify the stratospheric impact on the chemistry of the Arctic troposphere during the summer.
\end{abstract}

\section{INTRODUCTION}

Atmospheric radionuclides have long been recognized as valuable tracers of air mass mixing and transport processes [Rama, 1963; Junge, 1963; Bhandari et al., 1966, 1970; Feely and Seitz, 1970; Poet et al., 1972; Husain et al., 1977; Dutkiewicz and Husain, 1979, 1985; Viezee and Singh, 1980; Lambert et al., 1982]. The utility of atmospheric radionuclides for such applications depends on two major factors: (1) that the sources of radionuclides, both natural and anthropogenic, in the atmosphere are fairly well defined, and (2) that the majority of the radionuclides of interest rapidly become attached to atmospheric aerosols, but thereafter are largely passive tracers of these particles (with ${ }^{3} \mathrm{H}$ and ${ }^{14} \mathrm{C}$ being obvious exceptions). These unique features of atmospheric radionuclides suggest that improved understanding of their atmospheric distributions obtained from detailed measurements will facilitate refinement and validation of global circulation models.

Most of the early measurements of atmospheric radionu-

Copyright 1992 by the American Geophysical Union.

Paper number 91JD01807.

0148-0227/92/91JD-01807\$05.00 clides focused on anthropogenic isotopes produced during open-air testing of thermonuclear bombs. The levels of fallout isotopes in the atmosphere have recently returned to such low levels that they are rarely detectable at the surface, even during the spring-summer period of most extensive stratospheric-tropospheric exchange [Feely et al., 1988; Larsen and Sanderson, 1990]. Measurements of natural atmospheric radionuclides, primarily cosmogenic or endmembers of the uranium decay series, can greatly supplement the information already obtained from studies of the fallout isotopes.

The production rates of cosmogenic ${ }^{7} \mathrm{Be},{ }^{10} \mathrm{Be},{ }^{32} \mathrm{P},{ }^{33} \mathrm{P}$, and ${ }^{35} \mathrm{~S}$, and their spatial and temporal variations, have been predicted theoretically [Lal et al., 1958]. The important details of these predictions have now been experimentally confirmed [Lal et al., 1960; Rama, 1963; Bhandari et al., 1966]. Due to the relative ease of detection and quantification, ${ }^{7} \mathrm{Be}$ (half-life 53.3 days) has been one of the most studied cosmogenic radionuclides. The maximum production of ${ }^{7} \mathrm{Be}$ occurs near $15 \mathrm{~km}$ [Bhandari et al., 1970]. Once formed, ${ }^{7} \mathrm{Be}$ rapidly attaches to aerosols [Arnold and $\mathrm{Al}$ Salih, 1955], predominantly those in the submicron fraction [Maenhaut et al., 1979; Bondietti et al., 1987, 1988]. The 
combined effects of high ${ }^{7} \mathrm{Be}$ production rates in the stratosphere and the relatively rapid removal of aerosol-associated species from the troposphere produce stratospheric ${ }^{7} \mathrm{Be}$ concentrations about an order of magnitude higher than those just below the tropopause [Rama, 1963; Bhandari et al., 1966; Dutkiewicz and Husain, 1979, 1985]. Consequently, ${ }^{7} \mathrm{Be}$ is a sensitive indicator of intrusions of stratospheric air into the troposphere [Husain et al., 1977; Wolff et al., 1979; Dutkiewicz and Husain, 1979].

Some of the ${ }^{222} \mathrm{Rn}$ (half-life of 3.8 days) formed in the ${ }^{238} \mathrm{U}$ decay series escapes to the atmosphere, where it decays through a series of short-lived intermediates to ${ }^{210} \mathrm{~Pb}$ (halflife of 22.3 years). Unlike the noble gas $\mathrm{Rn}, \mathrm{Pb}$ (and all of the intermediate daughters) is metallic and rapidly associates with atmospheric particles [Turekian et al., 1977]. Like ${ }^{7} \mathrm{Be}$, most atmospheric ${ }^{210} \mathrm{~Pb}$ is concentrated on submicron aerosols [Maehhaut et al., 1979; Bondietti et al., 1987, 1988]. Radon flux to the atmosphere from the oceans is negligible compared to that from the continents [Turekian et al., 1977], so the ultimate source of atmospheric ${ }^{210} \mathrm{~Pb}$ is the continental boundary layer. However, enough ${ }^{222} \mathrm{Rn}$ enters the stratosphere to create a significant stratospheric ${ }^{210} \mathrm{~Pb}$ reservoir near the tropopause [Bhandari et al., 1966; Feely and Seitz, 1970; Lambert et al., 1982].

Three intensive, aircraft-based, atmospheric sampling campaigns have recently been conducted in the high-latitude region of the western hemisphere. Although measurement of selected atmospheric radionuclides was not a main focus of these research programs, 78 aerosol samples became available for the determination of ${ }^{210} \mathrm{~Pb}$ and 33 for ${ }^{7} \mathrm{Be}$. The distributions of ${ }^{7} \mathrm{Be}$ and ${ }^{210} \mathrm{~Pb}$ in the Arctic atmosphere revealed by this recent sampling suggest that our understanding of the structure and dynamics of the polar atmosphere is not yet complete. In this paper we demonstrate the potential usefulness of atmospheric radionuclides in furthering that understanding.

\section{MeTHODS}

The aerosol samples discussed here were collected during the NOAA Arctic Gas and Aerosol Sampling Program 3 (AGASP 3) in March 1989, and the NASA Global Tropospheric Experiment/Arctic Boundary Layer Expeditions (GTE/ABLE 3A and ABLE 3B) in July-August 1988 and 1990, respectively (Figure 1). AGASP 3 was based out of Bodo, Norway, and focused on the atmosphere over the pack ice near Spitsbergen [Schnell et al., 1991]. During ABLE 3A, most of the flights were in the vicinity of Barrow or Bethel, Alaska, but samples were collected on all transit flights (including two between Alaska and Thule, Greenland, as well as one flight over the pack ice northeast of Thule [Harriss et al., this issue]. ABLE 3B flights were mainly over northern Ontario and Labrador; however, most of the samples for atmospheric radionuclides were collected between Goose Bay, Labrador, and Frobisher Bay on Baffin Island. During ABLE 3B, very small air volumes were sampled (5-13 standard cubic meters $\left(\mathrm{m}^{3} \mathrm{STP}\right)$ ), as one of the objectives was to determine the finest temporal and spatial resolution with which ${ }^{7} \mathrm{Be}$ concentrations could be measured in the free troposphere.

On all three missions, atmospheric aerosols were collected on filters coupled directly to short inlet lines. Sample volumes were determined with integrating mass flowmeters.

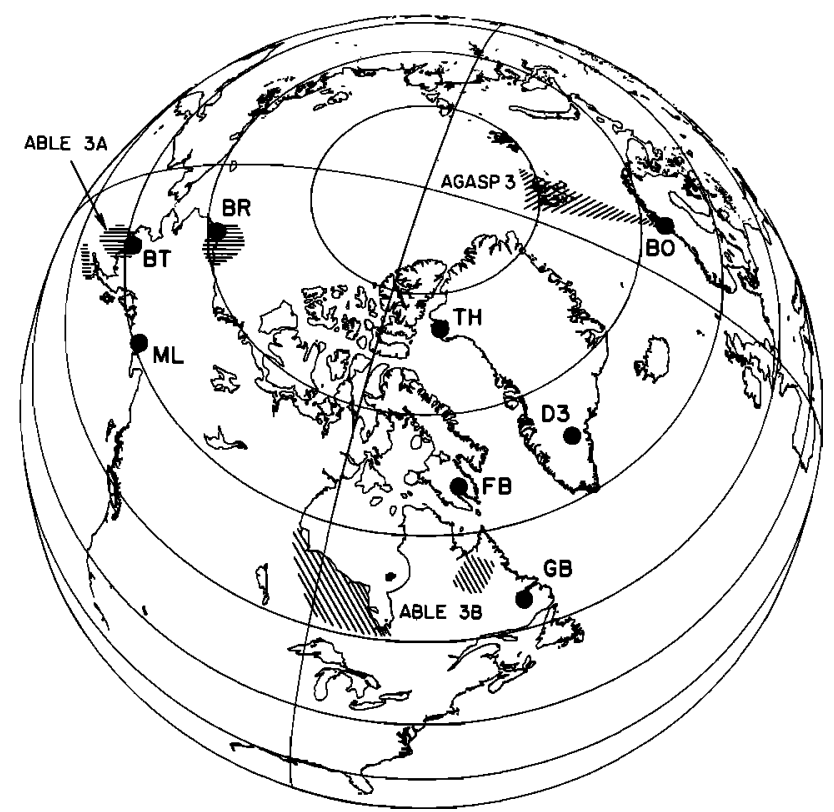

Fig. 1. Map of the Arctic Basin showing the general areas of aircraft operations during NASA GTE ABLE 3A (July-August 1988), NOAA AGASP 3 (March 1989), and NASA GTE ABLE 3B (July-August 1990). Also shown are the following ground locations discussed in the text: Bethel (BT), Barrow (BR), Mount Logan (ML), Thule (TH), Dye 3 (D3), Frobisher Bay (FB), Goose Bay (GB), and Bodo (BO).

Insofar as possible, sampling rates were adjusted to maintain isokinetic flow. Details of the aerosol sampling are reported elsewhere [Talbot et al., this issue]. The sharp-edged nozzle used on AGASP 3 may cause some loss of aerosols by deposition inside the inlet [Huebert et al., 1990] (P. Sheridan, personal communication, 1990). The curved leading edge nozzle employed on the ABLE missions appears to minimize these problems, especially for submicron-sized particles (R. W. Talbot et al., manuscript in preparation, 1991). For AGASP 3, particles were collected on $20 \times 25$ $\mathrm{cm}^{2}$ Whatman 41 filters. During ABLE 3A we used 90-mmdiameter Gelman E/A glass fiber filters and $90-\mathrm{mm}$-diameter Whatman GF/A glass fiber filters on ABLE 3B. After sample collection, the filters were folded in half (exposed side in) and sealed in polyethylene bags.

The activities of ${ }^{7} \mathrm{Be}$ and ${ }^{210} \mathrm{~Pb}$ on the filters were determined by nondestructive gamma spectrometry. Filters were crushed into $4-\mathrm{mL}$ polyethylene vials for counting in the germanium well detector in the Glacier Research Group's Keck Radionuclide Counting Laboratory (only one-half of each AGASP 3 filter was counted, with the other half being sent to D. Lowenthal at the University of Rhode Island for instrumental neutron activation analysis (INAA)). Due to the large sample load in the counting laboratory, none of the filters was counted longer than 24 hours. Calibration was accomplished by spiking blank filters with National Bureau of Standards (NBS) traceable standard solutions, then crushing these filters into the same geometry as the samples. Activities were corrected for decay between sampling and analysis. Repeated counting of standards, blanks, and aerosol filters from an ongoing study indicates that precision for 24-hour counts is approximately $150 \mathrm{fCi}{ }^{210} \mathrm{~Pb}$ and $250 \mathrm{fCi}$ 
AGASP 3 March 1989

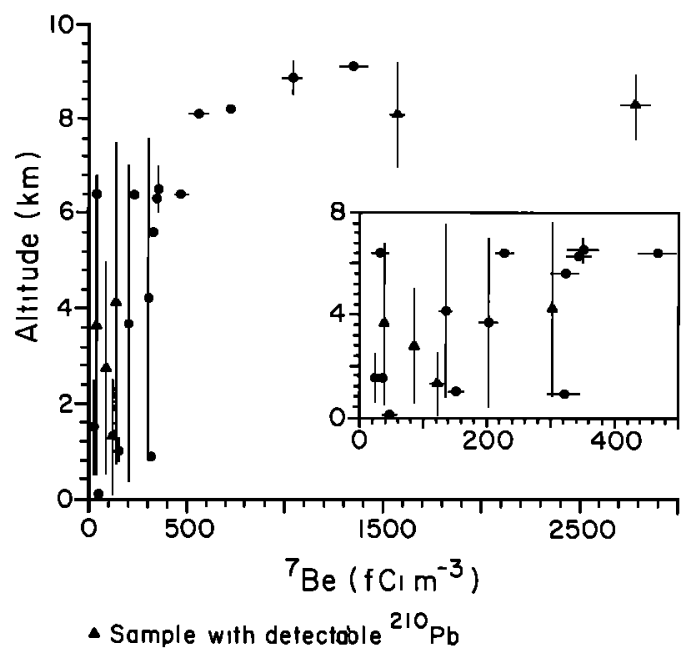

Fig. 2. Berylium 7 concentrations during AGASP 3. Samples that contained ${ }^{10} \mathrm{~Pb}$ are indicated by triangles. The horizontal error bars represent one-sigma counting uncertainties in the activity, while vertical bars depict the altitude range over which the samples were collected. The inset shows the lower altitude samples on an expanded concentration scale.

${ }^{7}$ Be. Filters from ABLE 3A did not become available until early 1990 , precluding determination of the ${ }^{7} \mathrm{Be}$ activity.

\section{RESULTS}

\section{AGASP 3}

Beryllium 7 was readily quantified on all 22 filters exposed during this mission (Figure 2). One-sigma counting uncertainties averaged $7 \%$ of the activity measured on the filters collected in the free troposphere. For the six samples collected in the boundary layer the average uncertainty was $15 \%$. Six samples collected near, or above, $8 \mathrm{~km}$, in air containing $>100 \mathrm{ppb} \mathrm{O}_{3}$, which was presumably stratospheric air, averaged $1330 \pm 800 \mathrm{fCi}^{7} \mathrm{Be}\left(\mathrm{m}^{3} \mathrm{STP}\right)^{-1}$, compared to an average of $198 \pm 138 \mathrm{fCi}^{7} \mathrm{Be}\left(\mathrm{m}^{3} \mathrm{STP}\right)^{-1}$ for all other samples.

Lead 210 was detectable on only six filters (Figure 2). The average concentration of the two samples with detectable ${ }^{210} \mathrm{~Pb}$ collected above $8 \mathrm{~km}\left(44.6 \mathrm{fCi} \mathrm{m}^{3} \mathrm{STP}\right.$ ) (which were also the samples with the highest ${ }^{7} \mathrm{Be}$ concentrations (Figure 2)) was more than 5 times higher than the average of the four lower altitude samples with detectable ${ }^{210} \mathrm{~Pb}\left(8.4 \mathrm{fCi}\left(\mathrm{m}^{3}\right.\right.$ STP) ${ }^{-1}$ ). Sample volumes on this mission ranged $7-153 \mathrm{~m}^{3}$ STP, with an average of 40 . If the precision of repeated ${ }^{210} \mathrm{~Pb}$ determinations is divided by the average volume, a very rough "working" detection limit of $4 \mathrm{fCi}\left(\mathrm{m}^{3} \mathrm{STP}\right)^{-1}$ can be estimated.

\section{$A B L E 3 A$}

Lead 210 was present above the detection limit on 22 of the 45 filters analyzed from this mission (Figure 3). (Sample volumes averaged $23 \mathrm{~m}^{3} \mathrm{STP}$ (range 14-43), giving a "detection limit" near $6 \mathrm{fCi}\left(\mathrm{m}^{3} \mathrm{STP}\right)^{-1}$.) The significantly higher percentage of samples with detectable ${ }^{210} \mathrm{~Pb}(49 \%)$, and higher average concentration for the ABLE 3A samples $\left(22.7 \mathrm{fCi}{ }^{210} \mathrm{~Pb}\left(\mathrm{~m}^{3} \mathrm{STP}\right)^{-1}\right)$, compared to $8.4 \mathrm{fCi}\left(\mathrm{m}^{3}\right.$
ABLE 3a July-August 1988

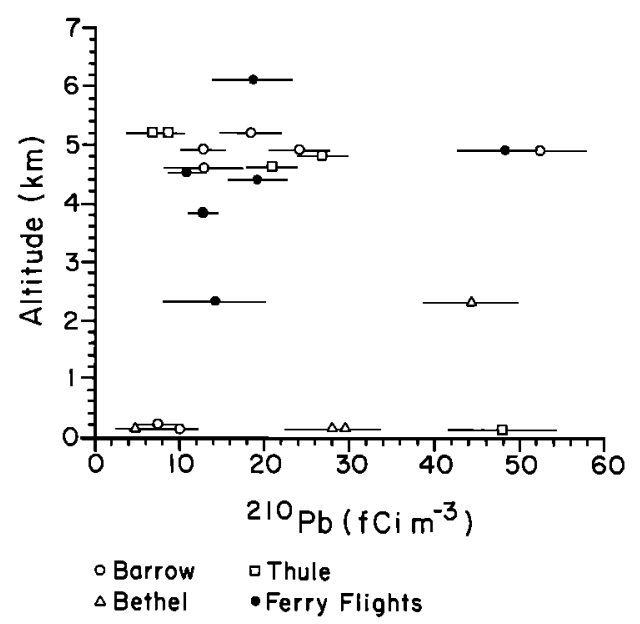

Fig. 3. Lead 210 concentrations during ABLE 3A. The horizontal error bars represent one-sigma counting uncertainties in the activity.

STP) ${ }^{-1}$ during AGASP 3 , suggests that there was considerably more atmospheric ${ }^{210} \mathrm{~Pb}$ in the North American Arctic troposphere in the summer of 1988 than was present over the ice between Greenland and Norway the following March. These observations will be discussed in more detail below.

\section{$A B L E 3 B$}

As was the case for AGASP $3,{ }^{7} \mathrm{Be}$ was readily quantified on all of the filters collected during this mission, despite the much smaller sampled volumes (Figure 4). Counting uncertainty averaged $15 \%$, improving to $10 \%$ when samples 8-1 and 19-4 (with very low ${ }^{7} \mathrm{Be}$ concentrations) are excluded. The average concentration of $229 \pm 105 \mathrm{fCi}{ }^{7} \mathrm{Be}\left(\mathrm{m}^{3} \mathrm{STP}\right)^{-1}$ is slightly, but not significantly, higher than observed below $8 \mathrm{~km}$ during AGASP 3 . The lower average, and wider range, in ${ }^{7} \mathrm{Be}$ concentration during AGASP 3 mainly reflects inclusion of samples from levels between the surface and $3 \mathrm{~km}$ and 6-8 $\mathrm{km}$ that were not sampled during ABLE $3 \mathrm{~B}$.

\section{ABLE 3b July-Augus† 1990}

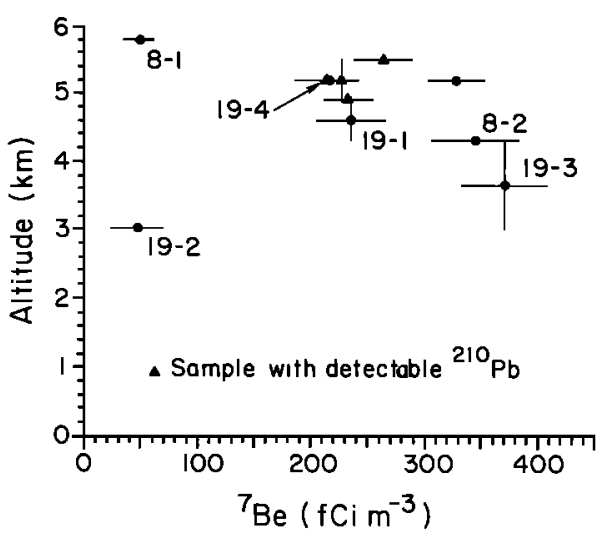

Fig. 4. Berylium 7 concentrations during ABLE 3B. Samples that contained ${ }^{210} \mathrm{~Pb}$ are indicated by triangles. The horizontal error bars represent one-sigma counting uncertainties in the activity, while vertical bars depict the altitude range over which the samples were collected. 
Lead 210 was detected on just four of the ABLE 3B filters (Figure 4). (The average volume of $9 \mathrm{~m}^{3}$ STP for these samples raises the "detection limit" to $15 \mathrm{fCi}\left(\mathrm{m}^{3} \mathrm{STP}\right)^{-1}$.) Interestingly, these samples were collected between 4.9 and $5.5 \mathrm{~km}$. The average ${ }^{210} \mathrm{~Pb}$ concentration in these four samples, $26.7 \mathrm{fCi}\left(\mathrm{m}^{3} \mathrm{STP}\right)^{-1}$, was quite similar to the 22.7 $\mathrm{fCi}\left(\mathrm{m}^{3} \mathrm{STP}\right)^{-1}$ average value during ABLE 3A.

\section{Discussion}

\section{Beryllium 7}

The composite ${ }^{7} \mathrm{Be}$ altitude profile observed during AGASP 3 (Figure 2) shows the expected rapid increase in concentration with increasing altitude. The "stratospheric" average of $1330 \mathrm{fCi}\left(\mathrm{m}^{3} \mathrm{STP}\right)^{-1}$ (as well as the highest concentration measured, $\left.2770 \mathrm{fCi}\left(\mathrm{m}^{3} \mathrm{STP}\right)^{-1}\right)$ is considerably lower than theoretical predictions and previously measured values for the stratosphere at these latitudes [Rama, 1963; Bhandari et al., 1966]. This finding suggests either that true stratospheric air was not sampled or that aerosol losses in the inlet were severe [Huebert et al., 1990]. However, the average of $198 \mathrm{fCi}^{7} \mathrm{Be}\left(\mathrm{m}^{3} \mathrm{STP}\right)^{-1}$ for all samples below 8 $\mathrm{km}$ (mainly below $6 \mathrm{~km}$ ) is in reasonable agreement with the

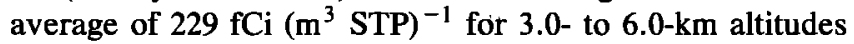
during ABLE 3B, indicating that loss of particles during sampling was probably not a major problem.

Beryllium 7 concentrations measured during ABLE 3B suggest the presence of a free tropospheric maximum near $4-5 \mathrm{~km}$ (Figure 4). Tropospheric concentrations of ${ }^{7} \mathrm{Be}$ are widely variable in space and time, reflecting differing histories of individual air masses. In particular, recent vertical motions (up or down) and scavenging by precipitation can greatly modify the horizontal and vertical distribution of ${ }^{7} \mathrm{Be}$ in the troposphere. The present ${ }^{7} \mathrm{Be}$ data set is admittedly sparse (only 11 samples from ABLE 3B), but several lines of evidence suggest that the observed maximum is real and may be a pervasive feature of the summer Arctic troposphere.

Berylium 7 samples were collected from more than one altitude on just two of the flights during ABLE 3B (flights 8 and 19). Both of these profiles show elevated levels of ${ }^{7} \mathrm{Be}$ near $4 \mathrm{~km}$ relative to higher altitudes (Figure 4). Examination of preliminary profiles of ozone and dewpoint for ABLE 3B flights 8 and 19 shows that the samples with relatively high ${ }^{7}$ Be were collected in layers showing sharp dewpoint depression and elevated ozone concentrations (near $60 \mathrm{ppb}$ ozone in comparison to values near $40 \mathrm{ppb}$ above and below). These three tracers together indicate that air masses near 4-5 $\mathrm{km}$ in the North American Arctic troposphere in the summer of 1990 had a stratospheric component. A synopsis of UV differential absorption lidar (DIAL) measurements during ABLE $3 \mathrm{~A}$ indicates that $>56 \%$ of the air masses encountered between 4 and $6 \mathrm{~km}$ in the summer of $1988 \mathrm{had}$ significantly enhanced ozone levels due to stratospheric intrusions [Browell et al., this issue]. Estimated values of potential vorticity also indicate significant inputs of stratospheric air should have been occurring over much of the ABLE 3A and 3B study areas [Sandholm et al., this issue]. Finally, the average ${ }^{7} \mathrm{Be}$ profile over Alaska at $70^{\circ} \mathrm{N}$ in the early 1960 s also showed a midtropospheric maximum, with the average concentration at $4.6 \mathrm{~km}\left(250 \pm 127 \mathrm{fCi}\left(\mathrm{m}^{3}\right.\right.$ STP) ${ }^{-1}$ ) considerably higher than those at 3.0 and $5.5 \mathrm{~km}$ $\left(151 \pm 48\right.$ and $159 \pm 32 \mathrm{fCi}\left(\mathrm{m}^{3} \mathrm{STP}\right)^{-1}$, respectively)
[Rama, 1963]. We hypothesize that this may be a common situation in summer, pointing to consideration of a stratospheric source for selected tropospheric species (e.g., $\mathrm{O}_{3}$, $\mathrm{SO}_{4}^{2-}, \mathrm{NO}_{y}$ [Gregory et al., this issue; Browell et al., this issue; Talbot et al., this issue; Wofsy et al., this issue; Sandholm et al., this issue].

Shapiro et al. [1987] showed that the Arctic jet stream causes significant stratosphere-troposphere exchange through tropopause folds, and that this jet will generally be near $70^{\circ}$ N. Raatz et al. [1985] present a detailed description of one such tropopause folding event encountered over Alaska during AGASP 1 (March 1983) near $65^{\circ}-70^{\circ} \mathrm{N}$, noting that, as observed for lower latitude tropopause folds [Danielsen, 1980; Johnson and Viezee, 1981], the stratospheric air injected into the troposphere through the fold tended to form a nearly horizontal layer between about 400 and $600 \mathrm{mbar}$ (approximately 4-7 km). No clear tropopause folds were encountered during the three missions presently under discussion, but layers of air in the free troposphere that retained a signature of a stratospheric source were common.

During AGASP 3, 32 profiles of ozone and dewpoint were obtained. In 14 cases, layers showing elevated ozone and depressed dewpoint were encountered in the troposphere, 12 of the 14 cases showed the layer to be between 4 and $5 \mathrm{~km}$. Similar layers of stratospherically influenced tropospheric air were very frequent during ABLE 3A' [Gregory et al., this issue; Browell et al., this issue]. Meteorologic analyses for the ABLE 3A flights suggest there was "significant stratosphere/troposphere exchange" in the area of aircraft operations on 11 of the 15 days when flights were near or north of $65^{\circ} \mathrm{N}$ [Shipham et al., this issue]. Interestingly, no exchange was predicted for the 12 flights near Bethel $\left(60^{\circ} \mathrm{N}\right)$. Average ozone profiles from all of the UV-DIAL measurements near Barrow and Bethel are similar below $2 \mathrm{~km}$, but the Barrow profile shows increasing enrichment above this altitude, with an average enhancement of $20 \mathrm{ppb}$ or more at $5 \mathrm{~km}$ [Browell et al., this issue]. Significant stratosphere-troposphere exchange was also indicated for all three of the transit flight legs near the polar jet stream at about $50^{\circ} \mathrm{N}$, in very good agreement with Shapiro et al.'s [1987] "threefold" structure of the northern hemisphere tropopause.

\section{Lead 210}

The very low ${ }^{210} \mathrm{~Pb}$ concentrations near Spitsbergen during AGASP 3 are surprising, given the extensive evidence from previous studies that this region of the Arctic is frequently influenced during the winter by heavily polluted air masses from Europe and Eurasia [e.g., Rahn et al., 1982; Iversen, 1984; Joranger and Ottar, 1984; Raatz, 1984; Raatz and Schnell, 1984; Iversen and Joranger, 1985]. The Arctic troposphere generally has $10-15$ times higher ${ }^{210} \mathrm{~Pb}$ concentrations in winter than summer, due to more efficient transport of air masses from these lower latitude continental source areas and reduced removal rates of aerosols [Rahn and McAffrey, 1980]. However, March 1989 was anomalous meteorologically, with the Arctic dominated by zonal winds which prevented the usual intrusions of mid-latitude air masses to higher latitudes [Herbert et al., 1990, 1991].

Lead 210 concentrations near Barrow were distinctly higher at $4.5-5.5 \mathrm{~km}$ than at lower levels, while the reverse trend is true near Bethel (Figure 3, Table 1). Talbot et al. 
TABLE 1. ${ }^{210} \mathrm{~Pb}$ Concentrations in the North American High-Latitude Troposphere During ABLE $3 A$ and ABLE 3B

\begin{tabular}{|c|c|c|c|c|c|}
\hline & $\begin{array}{l}\text { Ratio of } \\
\text { Number of } \\
\text { Samples With } \\
{ }_{210} \mathrm{~Pb} \text { to Total } \\
\text { Samples }\end{array}$ & $<1 \mathrm{~km}$ & $1.0-4.5 \mathrm{~km}$ & $4.5-5.5 \mathrm{~km}$ & $>5.5 \mathrm{~km}$ \\
\hline \multicolumn{6}{|c|}{$A B L E 3 A$} \\
\hline Thule & & 47.9 & - & 15.6 & - \\
\hline Barrow & $5 / 5$ & $\begin{array}{r}(1 / 1) \\
88\end{array}$ & $(0 / 0)$ & $(4 / 4)$ & $(0 / 0)$ \\
\hline Barrow & $8 / 16$ & $(2 / 7)$ & $\begin{array}{l}12.6 \\
(1 / 3)\end{array}$ & $\begin{array}{l}23.9 \\
(5 / 6)\end{array}$ & $\overline{(0 / 0)}$ \\
\hline Bethel & & 20.8 & 44.2 & - & - \\
\hline & $4 / 12$ & $(3 / 7)$ & $(1 / 3)$ & $(0 / 2)$ & $(0 / 0)$ \\
\hline Ferry & & - & 16.5 & 29.3 & 18.4 \\
\hline & $5 / 12$ & $(0 / 0)$ & $(2 / 4)$ & $(2 / 5)$ & $(2 / 3)$ \\
\hline All flights & & 21.3 & 28.4 & 21.9 & 18.4 \\
\hline & $22 / 45$ & $(6 / 15)$ & $(4 / 10)$ & $(11 / 17)$ & $(1 / 3)$ \\
\hline \multicolumn{6}{|c|}{$A B L E 3 B$} \\
\hline & $4 / 11$ & $\overline{(0 / 0)}$ & $\overline{(0 / 4)}$ & $\begin{array}{l}26.7 \\
(4 / 6)\end{array}$ & $\overline{(0 / 1)}$ \\
\hline
\end{tabular}

Concentrations are in $\mathrm{fCi} \mathrm{m} \mathrm{m}^{3} \mathrm{STP}$; averages calculated only for those samples where ${ }^{210} \mathrm{~Pb}$ was above the detection limit. Also shown (in parentheses) is ratio of the number of samples with ${ }^{210} \mathrm{~Pb}$ to the total number of samples.

[this issue] noted the same trend in comparing the concentrations of a range of aerosol species between the high Arctic $\left(>60^{\circ} \mathrm{N}\right.$, roughly equivalent to Barrow in Table 1 , but including high-latitude ferry flights and the samples collected near Greenland) and sub-Arctic $\left(50^{\circ}-60^{\circ} \mathrm{N}\right.$, essentially the flights near Bethel). These distributions were attributed to (1) long-range anthropogenic inputs and/or stratospheric inputs (at least for $\mathrm{SO}_{4}^{2-}$ ), (2) efficient removal of aerosolassociated species from the lower levels of the high Arctic troposphere due to the frequent occurrence of low-level fog banks and stratus cloud decks, and (3) a significant source of the aerosol species from surrounding oceans and sub-Arctic tundra at $50-60^{\circ} \mathrm{N}$. In addition, we observed approximately fourfold enrichment of $\mathrm{SO}_{4}^{2-}$ in free tropospheric $(>2 \mathrm{~km})$ "clean" air in the high Arctic compared to the sub-Arctic. Lead 210 appears to mimic this free tropospheric distribution of $\mathrm{SO}_{4}^{2-}$, suggesting common principal sources for these species.

Trajectory analyses for the ABLE 3A flights indicate that the air masses sampled near Barrow typically originated over eastern Asia, mainly Siberia, and were transported rapidly across the Bering Strait or Chukchi Sea. In contrast, trajectories for the Bethel flights where radionuclides were sampled indicated that the air masses originated ( 3 days prior to sampling) over the North Pacific. In this scenario, the free tropospheric samples collected near Bethel would be expected to have low ${ }^{210} \mathrm{~Pb}$ concentrations, while at lower levels, ${ }^{210} \mathrm{~Pb}$ may have a surface source from Alaska as the air masses moved onshore. Similarly, processing of the Siberian air masses by low-level stratus and fog banks could readily produce depleted ${ }^{210} \mathrm{~Pb}$ concentrations at lower levels near Barrow. However, the ${ }^{210} \mathrm{~Pb}$ concentrations from 4.5 to $5.5 \mathrm{~km}$ near Thule in 1988 and over northeastern Canada in 1990 (Table 1) are comparable to those at the same altitude near Barrow, but are not due to the same rapid transport from Siberia. Given the foregoing discussion of stratosphere-troposphere exchange in the northern hemisphere summer, and the relatively high ${ }^{210} \mathrm{~Pb}$ concentrations observed at the base of the stratosphere during AGASP 3 , we hypothesize that some of the ${ }^{210} \mathrm{~Pb}$ found near $5 \mathrm{~km}$ is stratospherically derived, and may be associated with stratospheric $\mathrm{SO}_{4}^{2-}$ aerosols injected into the troposphere near $70^{\circ} \mathrm{N}$.

A series of samples collected on the two ABLE 3A transit flights between Alaska and Greenland provide strong support for this hypothesis. During the long level transit flight legs near $5 \mathrm{~km}$ (between Greenland and Alaska, $70^{\circ}-76^{\circ} \mathrm{N}$ (Figure 1)), we intercepted air masses with sharp dew point depressions and highly elevated ozone concentrations between $107^{\circ} \mathrm{W}$ and $135^{\circ} \mathrm{W}$ on flight 4 and just east of $139^{\circ} \mathrm{W}$ on flight 28 (Figure 5). Aerosols collected over time intervals that included these air masses were enriched in ${ }^{210} \mathrm{~Pb}$ compared to other samples from these flights (Figure 5). Sample 4-2 also showed significant $\mathrm{SO}_{4}^{2-}$ enrichment, reaching a concentration of $150 \mathrm{ppt}$, the highest level observed at $4-5 \mathrm{~km}$ during ABLE $3 \mathrm{~A}$ (Figure 5).

If the stratosphere is a significant source of tropospheric $\mathrm{SO}_{4}^{2-}$ in the Arctic, the location of the polar and Arctic jets, and associated intensive stratosphere-troposphere exchange, may contribute to the poorly understood difference between ice core records of $\mathrm{SO}_{4}^{2-}$ deposition in South Greenland and the Yukon Territory. At Dye 3, Greenland $\left(65^{\circ} \mathrm{N}, 44^{\circ} \mathrm{W}\right)$, the concentration of $\mathrm{SO}_{4}^{2-}$ in recent snow is roughly threefold higher than in snow deposited at the turn of the century [Mayewski et al., 1990], while the record from Mount Logan $\left(60^{\circ} \mathrm{N}, 140^{\circ} \mathrm{W}\right)$ shows little or no change over this time period [Monaghan and Holdsworth, 1990]. Dye 3 is very near the location where the front associated with the Arctic jet generally intersects the surface [Shapiro et al., 1987], and therefore its chemical climatology may be strongly influenced by stratospherically derived air masses. On the other hand, Mount Logan is between the usual positions of the Arctic and polar jets and should generally reflect diffuse chemical effects of stratosphere-troposphere exchange. Such a latitudinal dependency of stratospheretroposphere exchange could also explain the fourfold enrich- 
a)

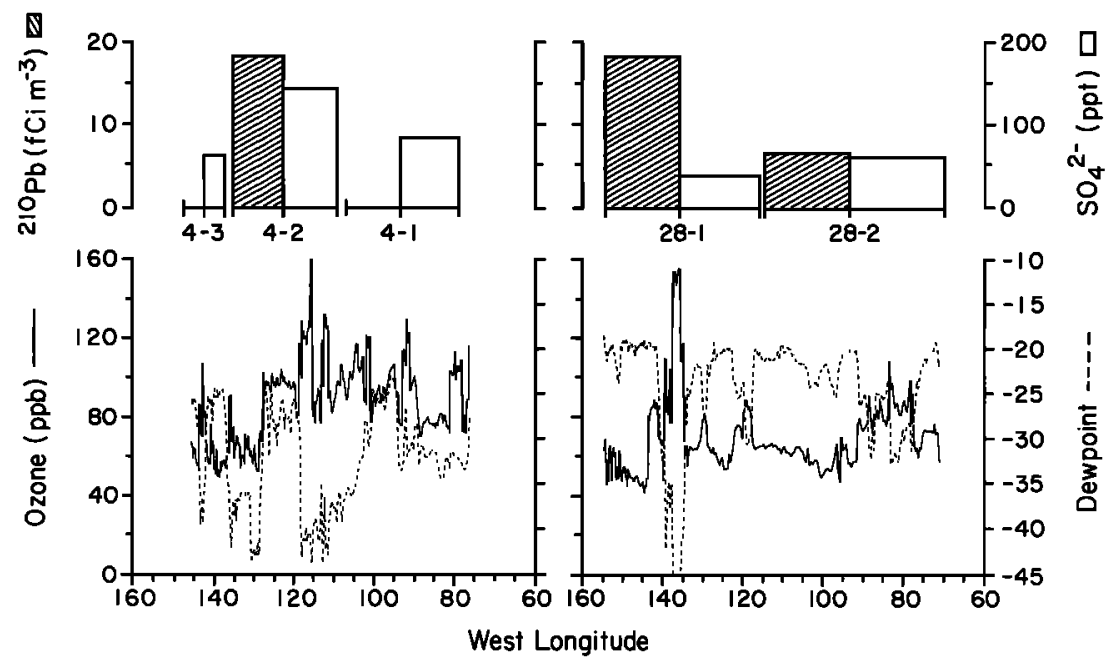

Fig. 5. Concentrations of ${ }^{210} \mathrm{~Pb}$ and $\mathrm{SO}_{4}^{2-}$ measured near $5 \mathrm{~km}$ during ABLE $3 \mathrm{~A}$ transit flights between Alaska and Greenland. Also shown are dewpoint and ozone during the flights. (a) Flight 4 was westbound on 9 July; (b) flight 28 was eastbound on August 12, 1988.

ment of $\mathrm{SO}_{4}^{2-}$ in "clean" free tropospheric air over Barrow relative to Bethel. This hypothesis implies, of course, that the stratospheric $\mathrm{SO}_{4}^{2-}$ reservoir has been greatly enriched by anthropogenic emissions, as has been recently suggested [Hofmann and Rosen, 1980; Sedlacek et al., 1983; Hofmann, 1990]. Perhaps more important, this also implies that the impact of anthropogenic $\mathrm{SO}_{4}^{2-}$ on the summer Arctic troposphere is significantly moderated by stratosphere-troposphere exchange processes. This intriguing possibility merits further investigation, including examination of latitudinal differences in $\mathrm{SO}_{4}^{2-}$ depositional trends for the past century (from snow and ice records) and additional atmospheric sampling throughout the Arctic.

\section{SUMMARY}

Beryllium 7 concentrations measured during the AGASP 3 mission north and west of Norway are in accord with previous results for high northern latitudes, but suggest that the "stratospheric" air masses sampled at the highest elevations reached were significantly diluted with tropospheric air. Higher resolution sampling (in terms of time and space, particularly in the vertical) in the free troposphere of the North American Arctic during ABLE 3B revealed a layer of elevated ${ }^{7} \mathrm{Be}$ concentrations near $5 \mathrm{~km}$. A similarly enriched layer was documented, but not discussed, by Rama [1963] in a compilation of all ${ }^{7} \mathrm{Be}$ data obtained near $70^{\circ} \mathrm{N}$ during the major sampling efforts investigating bomb fallout in the late 1950 s to early $1960 \mathrm{~s}$. The presence of a layer of stratospherically derived air at about this level in the troposphere is an expected consequence of tropopause fold events and may be a common feature of the North American Arctic troposphere, particularly in the summer.

The distribution of ${ }^{210} \mathrm{~Pb}$ in the high-latitude troposphere of North America during the summer was quite similar to distributions of more frequently measured aerosol species (e.g., $\mathrm{SO}_{4}^{2-}$ ). At latitudes above $65^{\circ} \mathrm{N}$, free tropospheric concentrations tended to increase with altitude up to at least $5.5 \mathrm{~km}$, while the concentrations near $60^{\circ} \mathrm{N}$ tended to be higher near the surface than at $4-6 \mathrm{~km}$. Lead 210 concentrations in the high Arctic troposphere between Greenland and Norway in March 1989 were probably anomalously low, but two samples of mixed stratospheric and tropospheric air above $8 \mathrm{~km}$ contained ${ }^{210} \mathrm{~Pb}$ at levels greater than fivefold higher than the tropospheric samples from the same area and nearly twice as high as the average concentration seen at 4-6 km in the North American summer troposphere. A partial explanation for the elevated ${ }^{210} \mathrm{~Pb}$ levels seen near $5 \mathrm{~km}$ in the summer in the North American Arctic (and perhaps the similar $\mathrm{SO}_{4}^{2-}$ enrichment reported by Talbot et al. [this issue]) may be stratospheric intrusions through tropopause folds, as was discussed in connection with the layer of elevated ${ }^{7} \mathrm{Be}$ seen during ABLE 3B. Detailed measurements of selected meteorological and chemical parameters, including ${ }^{7} \mathrm{Be}$ and ${ }^{210} \mathrm{~Pb}$, are needed to begin quantification of the stratospheric flux of material into the Arctic troposphere and assessment of the influence of such fluxes on the composition of the troposphere.

Acknowledgments. We would like to thank R. Schnell for providing samples from AGASP 3, and the staff of the NOAA Office of Aircraft Operations and the P-3 flight crew for making that a successful mission. Thanks are also due R. Harriss, the staff of the NASA Wallops Flight Facility, and the crew of the Electra research aircraft for making it possible to collect samples during the two ABLE missions. This research was supported by the NASA Global Tropospheric Chemistry program.

\section{REFERENCES}

Arnold, J. R., and H. A. Al-Salih, Berylium-7 produced by cosmic rays, Science, $121,451-453,1955$.

Bhandari, N., D. Lal, and Rama, Stratospheric circulation studies based on natural and artificial radioactive tracer elements, Tellus, $18,391-405,1966$.

Bhandari, N., D. Lal, and Rama, Vertical structure of the troposphere as revealed by radioactive tracer studies, J. Geophys. Res., 75, 2974-2980, 1970.

Bondietti, E. A., C. Papastefanou, and C. Rangarajan, Aerodynamic size associations of natural radioactivity with ambient 
aerosols, in Radon and Its Decay Products: Occurrence, Properties and Health Effects, Symp. Ser. 331, edited by P. K. Hopke, pp. 377-397, American Chemical Society, Washington, D. C., 1987.

Bondietti, E. A., J. N. Brantley, and C. Rangarajan, Size distributions and growth of natural and Chernobyl-derived submicron aerosols in Tennessee, J. Environ. Radioact., 6, 99-120, 1988.

Browell, E. V., C. F. Butler, S. A. Kooi, M. A. Fenn, R. C. Harriss, and G. L. Gregory, Large-scale variability of ozone and aerosols in the summertime Arctic and sub-Arctic troposphere, J. Geophys. Res., this issue.

Danielsen, E. F., Stratospheric source for unexpectedly large values of ozone measured over the Pacific Ocean during Gametag, August 1977, J. Geophys. Res., 85, 401-412, 1980.

Dutkiewicz, V. A., and L. Husain, Determination of stratospheric ozone at ground level using ${ }^{7} \mathrm{Be} /$ ozone ratios, Geophys. Res. Lett., 6, 171-174, 1979.

Dutkiewicz, V. A., and L. Husain, Stratospheric and tropospheric components of ${ }^{7} \mathrm{Be}$ in surface air, J. Geophys. Res., 90, 5783$5788,1985$.

Feely, H. W., and H. Seitz, Use of Lead 210 as a tracer of transport processes in the stratosphere, J. Geophys. Res., 75, 2885-2894, 1970.

Feely, H. W., R. J. Larsen, and C. G. Sanderson, Annual report of the surface air sampling program, Rep. $E M L-497,165$ pp., U.S. Dep. of Energy, Washington, D. C., 1988.

Gregory, G. L., B. E. Anderson, L. S. Warren, E. V. Browell, D. R. Bagwell, and C. H. Hudgins, Tropospheric ozone and aerosol observations: The Alaskan Arctic, J. Geophys. Res., this issue.

Harriss, R. C., et al., The Arctic Boundary Layer Expedition (ABLE 3A): July-August 1988, J. Geophys. Res., this issue.

Herbert, G. A., B. J. B. Stunder, R. C. Schnell, B. A. Bodhaine, and S. J. Oltmans, Meteorological conditions during the AGASPIII flights, March 1989, EOS Trans. AGU, 71, 1262, 1990.

Herbert, G. A., et al., Meteorological conditions during the AGASP-III flights, March 1989, Atmos. Environ., in press, 1991.

Hofmann, D. J., Increase in the stratospheric background sulfuric acid aerosol mass in the past 10 years, Science, 248, 996-1000, 1990.

Hofmann, D. J., and J. M. Rosen, Stratospheric sulfuric acid layer: Evidence for an anthropogenic component, Science, 208, 1368$1370,1980$.

Huebert, B. J., G. Lee, and W. L. Warren, Airborne aerosol inlet passing efficiency, J. Geophys. Res., 95, 16,369-16,381, 1990.

Husain, L., P. E. Coffey, R. E. Meyers, and R. T. Cederwall, Ozone transport from stratosphere to troposphere, Geophys. Res. Lett., 4, 363-365, 1977.

Iversen, $\mathrm{T}$., On the atmospheric transport of pollution to the Arctic, Geophys. Res. Lett., 11, 457-460, 1984.

Iversen, T., and E. Joranger, Arctic air pollution and large scale atmospheric flows, Atmos. Environ., 19, 2099-2108, 1985.

Johnson, W. B., and W. Viezee, Stratospheric ozone in the lower troposphere, 1, Presentation and interpretation of aircraft measurements, Atmos. Environ., 15, 1309-1323, 1981.

Joranger, E., and B. Ottar, Air pollution studies in the Norwegian Arctic, Geophys. Res. Lett., 11, 365-368, 1984.

Junge, C. E., Studies of global exchange processes in the atmosphere by natural and artificial tracers, J. Geophys. Res., 68, 3849-3856, 1963.

Lal, D., P. K. Malhotra, and B. Peters, On the production of radioisotopes in the atmosphere by cosmic radiation and their application to meteorology, J. Atmos. Terr. Phys., 12, 306-328, 1958.

Lal, D., J. R. Arnold, and M. Honda, Cosmic-ray production rates of ${ }^{7} \mathrm{Be}$ in oxygen and $\mathrm{P}^{32}, \mathrm{P}^{33}, \mathrm{~S}^{35}$ in argon at mountain altitudes, Phys. Rev., 118, 1626-1632, 1960.

Lambert, G., G. Polian, J. Sanak, B. Ardouin, A. Buisson, A. Jegou, and J. C. le Roulley, Cycle du radon et de ses descendants: Application a l'etude des echanges troposphere-stratosphere, Ann. Geophys., 38, 497-531, 1982.

Larsen, R. J., and C. G. Sanderson, Annual report of the surface air sampling program, Rep. EML-524, 120 pp., U.S. Dep. of Energy, Washington, D. C., 1990.
Maenhaut, W., W. H. Zoller, and D. G. Coles, Radionuclides in the South Pole atmosphere, J. Geophys. Res., 84, 3131-3138, 1979.

Mayewski, P. A., W. B. Lyons, M. J. Spencer, M. S. Twickler, C. F. Buck, and S. Whitlow, An ice-core record of atmospheric response to anthropogenic sulphate and nitrate, Nature, 346, $554-556,1990$.

Monaghan, M. C., and G. Holdsworth, The origin of non-sea-salt sulphate in the Mount Logan ice core, Nature, 343, 245-248, 1990.

Poet, S. E., H. E. Moore, and E. A. Martell, Lead-210, Bismuth210, and Polonium-210 in the atmosphere: Accurate ratio measurement and application to aerosol residence time determination, J. Geophys. Res., 77, 6515-6527, 1972.

Raatz, W. E., Tropospheric circulation patterns during the Arctic Gas and Aerosol Sampling Program (AGASP), March/April 1983, Geophys. Res. Lett., 11, 449-452, 1984.

Raatz, W. E., and R. C. Schnell, Aerosol distribution and an Arctic aerosol front during AGASP: Norwegian Arctic, Geophys. Res. Lett., 11, 373-376, 1984.

Raatz, W. E., R. C. Schnell, M. A. Shapiro, S. J. Oltmans, and B. Bodhaine, Intrusions of stratospheric air into Alaska's troposphere, March 1983, Atmos, Environ., 19, 2153-2158, 1985.

Rahn, K. A., and R. J. McAffrey, On the origin of the winter Arctic aerosol, Ann. N. Y. Acad. Sci., 338, 486-503, 1980.

Rahn, K. A., C. Brosset, B. Ottar, and E. M. Patterson, Black and white episodes, chemical evolution of Eurasian air masses, and long-range transport of carbon to the Arctic, in Particulate Carbon: Atmospheric Life Cycle, edited by G. T. Wolff and R. L. Klimisch, pp. 327-342, Plenum, New York, 1982.

Rama, Atmospheric circulation from observations of natural radioactivity, J. Geophys. Res., 68, 3861-3866, 1963.

Sandholm, S. T., et al., Summertime tropospheric observations related to $\mathrm{N}_{x} \mathrm{O}_{y}$ distributions and partitioning over Alaska: Arctic Boundary Layer Expedition 3A, J. Geophys. Res., this issue.

Schnell, E., et al., Arctic haze and the Arctic Gas and Aerosol Sampling Program (AGASP 3), Atmos. Environ., in press, 1991. Sedlacek, W. A., E. J. Mroz, A. L. Lazrus, and B. W. Ganrud, A decade of stratospheric sulfate measurements compared with observations of volcanic eruptions, J. Geophys. Res., 88, 37413776,1983

Shapiro, M. A., T. Hampel, and A. J. Krueger, The Arctic tropopause fold, Mon. Weather Rev., 115, 444 454, 1987.

Shipham, M. C., A. S. Bachmeier, D. R. Cahoon, Jr., and E. V. Browell, Meteorological overview of the Arctic Boundary Layer Expedition (ABLE 3A) flight series, J. Geophys. Res., this issue.

Talbot, R. W., A. S. Vijgen, and R. C. Harriss, Soluble species in the Arctic summer troposphere: Acidic gases, aerosols, and precipitation, J. Geophys. Res., this issue.

Turekian, K. K., Y. Nozaki, and L. K. Benninger, Geochemistry of atmospheric radon and radon products, Annu. Rev. Earth Planet. Sci., 5, 227-255, 1977.

Viezee, W., and W. B. Singh, The distribution of beryllium-7 in the troposphere: Implications on stratospheric/tropospheric exchange, Geophys. Res. Lett., 7, 805-808, 1980.

Wofsy, S. C., et al., Atmospheric chemistry in the Arctic and sub-Arctic: Influence of natural fires, industrial emissions, and stratospheric inputs, J. Geophys. Res., this issue.

Wolff, G. T., M. A. Ferman, and P. R. Monson, The distribution of beryllium-7 within high-pressure systems in the eastern United States, Geophys. Res. Lett., 6, 637-639, 1979.

J. E. Dibb, Glacier Research Group, Institute for the Study of Earth, Oceans and Space, University of New Hampshire, Durham, NH 03824.

G. L. Gregory, Atmospheric Sciences Division, NASA Langley Research Center, Hampton, VA 23665.

R. W. Talbot, Global Atmospheric Chemistry Group, Institute for the Study of Earth, Oceans and Space, University of New Hampshire, Durham, NH 03824.

(Received January 22, 1991; revised July 5, 1991; accepted July 5,1991 .) 